\title{
EL VINO DE RIOJA Y SU EXPANSIÓN DESDE LA POSGUERRA HASTA 1970: ANTONIO LARREA, EL HOMBRE DECISIVO
}

\author{
César Luena López \\ Universidad de La Rioja
}

\begin{abstract}
RESUMEN: Se exponen en este artículo las razones que permiten comprender la expansión del mundo del Rioja, los orígenes de la conquista de la calidad, la presencia en los mercados del mundo y la evolución del concepto "cultura del vino", a través de la obra de Antonio Larrea, el hombre que dirigió las instituciones fundamentales del Rioja entre 1944 y 1971 y que abordó con decisión los problemas para llegar a la Denominación Calificada y al éxito rotundo del "modelo Rioja".
\end{abstract}

Palabras clave: Vino de Rioja, Antonio Larrea, Estación Enológica de Haro, Consejo Regulador de la DOC Rioja, historia del Rioja.

\section{THE RIOJA WINE AND ITS EXPANSION BETWEEN THE POSTWAR AND 1970: ANTONIO LARREA, THE DECISIVE MAN}

\begin{abstract}
This paper presents the reasons that allowed the understanding of the expansion of the world of Rioja, the origins of the quality conquist, the worldwide market presence and the evolution of the concept "wine culture", through the works of Antonio Larrea, the man that directed the main Rioja institutions between 1944 and 1971, and who approached with decision the challenges to arrive to the Qualified Designation and to the great success of the "Rioja model".
\end{abstract}

Keywords: Rioja wine, Antonio Larrea, Haro Enological Station, Regulatory Board of the DOC Rioja, Rioja history. 
En el proyecto suscrito por la Fundación Vivanco y la Universidad de La Rioja para investigar el Fondo Larrea' se señalaba la riqueza de la documentación acumulada por Antonio Larrea a lo largo de su vida y su potencialidad para ampliar el conocimiento sobre el Rioja "en un periodo decisivo", lo que permitiría que un equipo de investigadores, entre los que me encuentro, trabajara en los muy variados aspectos que abarca ese fondo y que, en definitiva, fueron los que interesaron al ingeniero director de la Enológica y presidente del Consejo Regulador. Este fondo es una gran colección de documentos, depositada junto a otras grandes colecciones en el Centro de Documentación de la Fundación Vivanco de la Cultura del $\mathrm{Vino}^{2}$, compuesto por más de 130 cajas de documentos, así como algunas carpetas sueltas e incluso objetos personales de don Antonio Larrea.

Además de este valioso fondo, otras fuentes complementarias nos han permitido profundizar en las claves que iban a hacer del Rioja un mundo en expansión económica y un marco de cultura, tal y como quería Larrea. Por una parte, las memorias anuales de la Estación de Viticultura y Enología de Haro 3 , que desde nuestro punto de vista son la obra cumbre de Larrea; por otra, la documentación conservada en el Consejo Regulador de la Denominación de Origen Calificada Rioja, especialmente las actas de sus plenos ${ }^{4}$; y por supuesto, la documentación complementaria del Archivo Histórico Provincial de La Rioja.

Todo ello nos permite plantear la principal hipótesis de nuestro trabajo: la existencia de una etapa decisiva para la trasformación del Rioja en un modelo económico de éxito, que coincide con el tiempo en que Larrea fue director de la Enológica de Haro y presidente del Consejo Regulador, entre 1944 y 1971. La documentación, especialmente los muchos documentos que dejó, entre ellos, toda su obra, permiten trazar los primeros rasgos de la fase decisiva del Rioja que culmina en 1970, con la Ley del vino, la atracción de la Comunidad Económica Europea y la preparación de la concesión de la Calificada en 1991.

\section{Las contradicciones históricas}

El Rioja ha sido históricamente el sector por el que se ha conocido la región; los hombres del Rioja han llevado el nombre de las grandes bodegas por España durante los dos últimos siglos y han logrado consolidar la marca; todo el sector

1. El proyecto "Antonio Larrea, alma del Rioja, a través de los fondos documentales del Centro de Documentación del Vino Dinastía Vivanco", según acuerdo vía Oficina de Transferencia de los Resultados de la Investigación (OTRI), fue suscrito entre la Fundación Vivanco de la Cultura del Vino y la Universidad de La Rioja y su Departamento de Ciencias Humanas, bajo la responsabilidad de José Luis Gómez Urdáñez, catedrático de Historia Moderna del citado Departamento.

2. En adelante FL Vivanco.

3. Ver AEVEH (Archivo de la Estación de Viticultura y Enología de Haro), memorias.

4. Ver ACRDOCR (Archivo del Consejo Regulador de la Denominación de Origen Calificada Rioja), actas. 
y sus apoyos han conseguido que el mundo del Rioja haya sido percibido como un formidable lobby que imponía su prestigio, en España y en el mundo, y que como sabía hacer mejor que nadie las cosas, fuera considerado un modelo a seguir, sobre todo desde que consiguió del dictador Primo de Rivera la primera Denominación de Origen; ${ }^{5}$ incluso, si vamos hacia atrás, desde que logró crear la primera Estación Enológica, ${ }^{6}$ la mejor dotada y sin duda, la más activa y prestigiosa. Todo esto parece más un preámbulo típico de la propaganda a la que estamos acostumbrados que una introducción a un trabajo académico; y sin embargo se expone así para producir, por contraste, un efecto que sorprenderá, como es la afirmación de que, con eso y todo, la cultura y la historia del vino en La Rioja todavía están en la infancia de su desarrollo, si no dando los primeros pasos, sí echando a andar.

Así pues, en los años cincuenta apenas había un par de artículos de historia y otros tantos sobre el vino como alimento, mientras se divulgaban otros aspectos agrarios, importantes en la economía riojana como habían sido siempre las conservas, $^{7}$ y se debatía en la sociedad riojana sobre el futuro de una economía que, como la española, no terminaba de salir del atraso. Larrea acudía presto a esta acción, que ya sabemos que formaba parte de su "apostolado", y publicaba un artículo titulado "Viticultura y enología riojanas", que iba a ser el origen del libro que publicaría años después. ${ }^{8}$ El artículo repasaba las condiciones naturales de la región, la historia, etc. y se detenía en el nombre de Rioja, que constituirá una de sus obsesiones hasta el punto de que un cuarto de siglo después dedicará al tema la lección de ingreso como miembro de número del Instituto de Estudios Riojanos. Solo al final aparecía el tema "la riqueza vitivinícola", que por lo que podemos comprobar al repasar sus notas y el resto de artículos de divulgación escritos por él en esos años, no pasaba de ser una simple introducción. Era obvio que Larrea preparaba una serie, pero ya no volvió a publicar nada en Berceo hasta muchos años después, en 1974. Así pues, entre 1951 y 1974, sin que sepamos por qué, Larrea, que siguió escribiendo febrilmente en cualquier tipo de medio,

5. Gómez Urdáñez, J. L. (dir.) (2000), El Rioja histórico. La Denominación de Origen y su Consejo Regulador. Consejo Regulador, Logroño, pp. 88-92.

6. Sobre la Estación de Viticultura y Enología de Haro, véase De la Fuente Rosales, F. (2011), Temas Jarreros II, "Capítulo 7. La Estación Enológica", pp. 321-393. Ayuntamiento de Haro, Haro; Egido, A. (2005), La Estación Enológica de Haro. Un referente para la ciencia y la técnica del vino desde 1892. Ediciones La prensa del Rioja, Logroño y Pascual Corral, J. y León Sáenz, J. (coords.) (1992), 1892-1992. Estación Enológica de Haro, cien años de historia. Gobierno de La Rioja, Consejería de Agricultura y Desarrollo Rural, Logroño.

7. Gómez Urdáñez, J. L. (dir.), Empresarios trabajadores...; Sáenz Cenzano, Salvador, "Estado actual y posibilidades de la agricultura en La Rioja", Berceo, no 20, 1951, pp. 357-374. El propio Ochagavía escribirá luego una interesante historia textil riojana y unas notas sobre la industria conservera.

8. Larrea Redondo, Antonio, "Viticultura y enologías riojanas", Berceo, n 20, 1951, pp. 343-356. 
dejó de colaborar con la revista y ésta no volvió a ocuparse del vino hasta un lustro después.

En suma, los años setenta y principios de los ochenta casi se puede decir que representaron un retroceso en el mundo cultural del Rioja, que ya no mostró hasta mucho tiempo después su "cara amable". Nada se avanzó en la historia en La Rioja, aunque fuera siguió habiendo importantes publicaciones, como el ya clásico libro de Alain Huetz de Lemps sobre vinos y viñedos del Noroeste de España -incluyendo La Rioja-, publicado en Burdeos en 1967.9 Los dos volúmenes del gran maestro pasaron desapercibidos en los setenta y sólo al comienzo de los ochenta serían conocidos entre algunos profesores del Colegio Universitario de Logroño, creado en 1972, pero todavía más entre geógrafos que por los historiadores. Tampoco tendría mucha difusión el gran libro de García Delgado sobre la "cuestión agraria" en España, editado en 1976, y tantos otros, incluyendo la célebre "Estructura económica de España", de Ramón Tamames, que lleva ya más de treinta ediciones, y que significaron un hito en los intentos de explicación de lo que entonces ya se afirmaba sin paliativos: el fracaso de la agricultura española. ${ }^{10}$

Podría parecer que la concesión de la Calificada en 1991 había propiciado aportaciones a la historia y la cultura, pero no es así. No hubo hasta el final de la década nada planificado y si entre 1995 y la publicación de El Rioja histórico, en el 2000, hubo en Berceo media docena de artículos se debió a la inquietud de algunos historiadores consagrados como Eliseo Sáinz Ripa, Alfredo Ollero de la Torre, o María de los Ángeles de las Heras, beneméritos profesores del Instituto Sagasta, que siempre trabajaron y a los que rendimos reconocimiento por su labor. Junto a sus trabajos sobre historia del vino, Berceo acogía el artículo de Navajas Zubeldia, que años después sería profesor de la UR, sobre la creación de la Denominación en 1925, poco antes de que se cumpliera el 75 aniversario, y con un buen planteamiento de las tensiones entre cosecheros y "comerciantes" que venían dominando las relaciones entre estos dos elementos dispares desde antes de la filoxera. Un artículo del ya conocido Teodoro Lasanta, también sobre cifras de precios y mercado, y otro sobre testimonios arqueológicos, de Rosa Aurora Luezas, bien documentado y de enorme interés por lo que tenía de búsqueda de los remotos orígenes, no ya en los textos de Avieno o Estrabón, mil veces citados, sino en los hallazgos arqueológicos. ${ }^{11}$

9. Huetz de Lemps, A. (1967), Vignobles et vins du nord-ouest de l'Espagne. Burdeos, Presses Universitaires de Bordeaux.

10. García Delgado, J. L. (coord.) (1976), La cuestión agraria en la España contemporánea. EDICUSA, Madrid; Tamames, Ramón (1970), Estructura económica de España, Madrid.

11. "La vitivinicultura altomedieval riojana y la miniatura mozárabe Autores", María de los Ángeles de las Heras y Núñez, Berceo, no 129, 1995, pp. 97-112; “Viñas y vinos en la comarca calceatense durante los siglos XIII, XIV y XV", Eliseo Sáinz Ripa, Berceo, no 129, 1995, pp. 113-137; "La comercialización del vino en La Rioja durante el siglo XVIII", Alfredo Ollero de la Torre, Berceo, no 129, 1995, pp. 157-167; "'Cosecheros' contra 'comerciantes'. Los antecedentes inmediatos de la creación del Consejo Regulador de la Denominación Vinícola 'Rioja'", Carlos Navajas Zubeldia, Berceo, n 129, 1995, pp. 175-188; "Evolución reciente del mercado 
La "década prodigiosa" en todos los sentidos aún tuvo alguna aportación de importancia en la bibliografía riojana, sobre todo en el marco de la Universidad de La Rioja, creada en 1992, y una excepción en el libro dedicado a la historia de la Enológica al cumplir el centenario, del que hablaremos luego en extenso. Específicamente, la historia del vino no fue objeto todavía de estudios singulares al amparo de la UR, pero ya no podía faltar tratar algún aspecto en la mayoría de trabajos, tesinas y tesis doctorales. Así, Jesús Javier Alonso Castroviejo, en su tesis doctoral sobre la crisis del Antiguo Régimen en Logroño, no dejó de considerar el mundo del vino como uno de los aspectos significativos de la crisis que afectó a la ciudad a principios del XIX, precisamente a causa de la sobreproducción y los problemas - no resueltos por la Sociedad Económica de Amigos del País de La Rioja en décadas anteriores- en la comercialización. Desde entonces, Alonso Castroviejo ha escrito importantes artículos sobre historia del Rioja, entre ellos un excelente estado de la cuestión. ${ }^{12}$ También es de resaltar los trabajos de Francisco Bermejo desde que en 1993 publicara un excelente artículo sobre la economía riojana, después de escribir la mejor historia de la Diputación provincial en $1989,{ }^{13}$ y desde luego, la obra, dedicada a la vitivinicultura del profesor Emilio Barco, que ya en los ochenta escribió la serie "Análisis de un sector", año tras año, a la que seguirían páginas definitivas sobre aspectos cruciales del Rioja, hasta llegar a su tesis doctoral defendida en $2013 .{ }^{14}$ Igualmente, es reseñable lo publicado en la Comunidad Autónoma Vasca o en Navarra, que comienzan en esta década a producir importantes estudios gracias a la labor pionera de Domingo Gallego, Oestreciher, Mees. ${ }^{15}$ Pero además, ésta es la época de los grandes libros de divulgación de la historia del vino en España, como por ejemplo, el de

del Rioja y cambios en el sector vitivinícola", Teodoro Lasanta Martínez, Berceo, n 136, 1999, pp. 193-214; "Testimonios arqueológicos en torno a la vid y el vino en La Rioja", Rosa Aurora Luezas Pascual, Berceo, no 138, 2000, pp. 7-38; "Historia y cultura del Rioja. El marqués de Murrieta", María Dolores Borrell Merlín, Berceo, no 150, 2006, pp. 169-188.

12. Alonso Castroviejo, J. J. (1992), Problemática agraria, solución burguesa, Logroño, 1750-1833, Logroño, IER; del mismo, "Estado historiográfico de la investigación sobre el viñedo en La Rioja. Siglos XIX y XX". I I Encuentro de historiadores de la Vitivinicultura Española. EI Puerto de Santa María, 2001, pp. 425-434.

13. Bermejo Martín, F. y Delgado, J. M. (1989), La Diputación Provincial de La Rioja. Logroño, 1989; del mismo "La economía riojana desde una perspectiva histórica", Papeles de Economía Española. Madrid, 1993.

14. Barco Royo, E. (2013), Factores determinantes del funcionamiento económico del sector vitivinícola en la Denominación de Origen Calificada Rioja (DOCa Rioja) y su adaptación a los cambios en el entorno económico. Tesis doctoral, Universidad de La Rioja, noviembre 2012.

15. Gallego Martínez, D. (1987), "El factor agrario riojano, 1855-1935. De la especialización vitícola a la diversificación de la producción agraria". Brocar no 12, pp. 45-88; Oestreicher, A. (1994a), "Algunos aspectos de la historia del sector vitivinícola Riojano, 1860-1915". Berceo no 127, IER, pp. 137-152; Mees, L. (1992), "La vitivinicultura en Navarra y La Rioja: Economía, sociedad y política de intereses (1850-1940)", Gerónimo de Ustáriz, Pamplona, 1992. 
Pan Montojo, primero su Vitivinicultura en España, publicado por el MAPA en 1992 y, después, más divulgativo, La bodega del mundo, de 1994.16

Pero si hay un texto que define el interés institucional que empezaba a despertar el mundo del Rioja, ése es el dedicado a los cien años de historia de la Enológica, cuyo prólogo es del mismísimo presidente del gobierno, José Ignacio Pérez Sáenz, el cual afirmará que "de todas las Estaciones creadas a partir del Real Decreto de 15 de enero de 1892, únicamente la de Haro ha sabido mantener no sólo su existencia ininterrumpida a lo largo de estos 100 años, sino también los objetivos básicos que regían la finalidad de su creación: estar al día en los procedimientos de análisis, métodos de elaboración y todo lo que rodea a los procesos de vinificación; mejorar la lucha contra el fraude y el uso indiscriminado de productos químicos que pueden afectar a las condiciones higiénico-sanitarias del vino; supervisión de los procesos de elaboración de vinos en aquellas bodegas que lo solicitasen; mantenimiento de un depósito de muestras de vino; labor docente y pedagógica". ${ }^{17}$ Como se ve, toda una declaración en favor de la exclusividad de una institución clave durante todo ese siglo, y que venía a llamar la atención en realidad sobre el carácter extraordinario de un mundo insuficientemente reivindicado a través de su estudio y análisis.

En definitiva, la "década prodigiosa" ponía al Rioja en cotas insospechadas solo una década antes, cuando todavía se notaban los efectos de aquella crisis del petróleo que dejó en las bodegas riojanas 800 millones de litros sin vender, con vinos imposibles producto de las cosechas de 1971 y 1972 ante los que fracasaron las firmas que habían desembarcado en Rioja, como Rumasa, y que sólo la buena práctica de pacientes enólogos pudo ir sustituyendo hasta alcanzar las famosas cosechas de 1981 y $1982 .{ }^{18}$ Luego, vendría la pretendida estabilización y, al final del periodo, "hacer bien los deberes", mejor que nadie, para conseguir la Calificada, un día de enorme trascendencia para el Rioja, que todavía pudo ver Antonio Larrea, el hombre que recibía homenajes, pero al que seguramente el mayor le pareció el día en que con la consejera de Agricultura Ana Leiva -a la que tuvo un gran aprecio personal-, y el presidente de La Rioja, José Ignacio Pérez, celebraron el galardón conseguido: la única Denominación Calificada de España.

16. Pan Montojo, J. (1992), La vitivinicultura en España, 1750-1988. MAPA, Madrid 1992; del mismo El Estado y la vid. Los orígenes de la política agraria en España a través de la vitivinicultura, 1847-1923, Madrid, Servicio de Publicaciones de la Universidad Autónoma de Madrid (edición en microfichas), 1993; del mismo La bodega del mundo. La vid y el vino en España. Madrid, 1994.

17. Pascual Corral, J. y León Sáenz, J. (coords.) (1992), 1892-1992. Estación Enológica de Haro, cien años de historia. Gobierno de La Rioja, Consejería de Agricultura y Desarrollo Rural, Logroño, p. 7.

18. El Rioja histórico..., pp. 165 y ss. 


\section{Antonio Larrea, alma del Rioja}

Larrea había nacido en Baeza, provincia de Jaén, el 14 de mayo de 1913, siendo bautizado en la parroquia de San Pablo nueve días después, el 23 de mayo, con el nombre de Antonio de Padua de la Santísima Trinidad Larrea Redondo. Su padre, Francisco, natural de Villadiego, era profesor en el Instituto de Enseñanza Media de Baeza y según los recuerdos de familiares, ${ }^{19}$ amigo de Antonio Machado, que había llegado al instituto de Baeza como catedrático de Francés en 1912 y seguramente celebró el bautizo de Antonio Larrea junto a su colega, que también se hallaba desplazado en aquel destino. La madre de Larrea, Felisa, era de Burgos, y su abuela, de Quintana; ésta fue madrina del bautismo, mientras el padrino fue su tío Pío Larrea. Los abuelos paternos eran de Badarán, tanto Adriano Larrea como Tomasa Rubio Morga. Años después, el catedrático Francisco Larrea acabó ganando la plaza en el Instituto de Enseñanza Media de Palencia, en fecha que no conocemos, pero es en esta ciudad donde tenemos los primeros datos de la vida del niño Larrea, aunque muy parcos. ${ }^{20}$

Cuando tiene ya los 17 años, encontramos a Larrea preparando el difícil examen de ingreso en la Escuela Especial de Ingenieros Agrónomos de Madrid, un centro decimonónico que, en 1931, había pasado de depender de diversos organismos del Ministerio de Agricultura al de Educación y a ocupar un espacio en la nueva ciudad universitaria que Alfonso XIII había creado en La Moncloa y La Florida. Larrea se presentó al examen en junio de 1930, pero sólo aprobó "Cultura General y Fundamentos filosóficos de las Ciencias", "Idioma Francés" y las "Matemáticas de Primer Grado". En septiembre de ese año, aprueba el Inglés y, en 1932, logra aprobar la "Biología General", las "Matemáticas de Segundo Grado" y los dos Dibujos, el "lineal acotado" y el "aplicado a las Ciencias Naturales", que debían de ser ya los "ogros" de las ingenierías. Así pues, en 1932, superado el ingreso, el joven Larrea se matriculó de primer curso. Sin embargo, en pocos meses, enfermó y, en febrero de 1933, ya "no abonó los derechos de examen ni se presentó a los mismos". ${ }^{21}$ La enfermedad era grave, nada menos que la tuberculosis, así que no se matriculó en el curso 1933-34. Su vuelta a los estudios tuvo lugar en el curso siguiente, que aprobó en junio de 1935 en su totalidad. Obtuvo notable en "Física General. Técnica micrográfica", en Química, Zoología, "Mineralogía y Geología aplicadas a la Ingeniería agronómica", y aprobado en el resto de las asignaturas: Botánica, Cálculo infinitesimal y Geometría descriptiva. Durante el segundo curso, 1935-36, aún tuvo tiempo de examinarse en junio, antes de que llegara la guerra, convocatoria en la que aprobó todas las

19. Entrevista con Amparo Larrea, 2 de noviembre de 2013.

20. Agradecemos a su sobrina Amparo Larrea los datos y aportaciones documentales facilitados. Contamos también con diversos documentos personales guardados en varias cajas del Fondo Larrea, Fundación Vivanco de la Cultura del Vino, Centro de Documentación.

21. Expediente personal de Antonio Larrea, amablemente facilitado por la Escuela Técnica Superior de Ingenieros Agrónomos de la Universidad Politécnica de Madrid. 
asignaturas menos la "Cosmografía, Climatología y Edafología", que superará tras el final de la guerra, en agosto de 1939. Había obtenido buena calificación en Química orgánica y "Economía política y social y Hacienda Pública", así como en el primer curso de Alemán; el resto, Botánica, "Geodesia y Topografía aplicadas al catastro" y la "Mecánica racional y aplicada a máquinas y construcciones" las superó con un aprobado.

La guerra interrumpió los estudios, que Larrea retomará en el curso 1940, según comprobamos por su expediente, aunque la Escuela Especial de Ingenieros Agrónomos, situada en la demolida ciudad universitaria, había sido destruida completamente $y$, según algunas versiones, no reemprendería las labores docentes hasta el curso siguiente, o incluso hasta $1942 .{ }^{22}$ Eso no debió ser obstáculo, sin embargo, para que el nuevo Régimen, necesitado de cuadros, hiciera exámenes a los alumnos que ya habían superado algunos cursos y rápidamente les diera el título para enviarlos a los muchos destinos que el Ministerio de Agricultura tenía que cubrir en pueblos y ciudades de la maltrecha España, que se había quedado sin poetas y escritores, pero también sin ingenieros y profesores universitarios, la mayoría muertos, o en los países que acogieron a los millares de exiliados españoles, entre ellos, grandes profesionales de todos los campos del saber. ${ }^{23}$ Así pues, en marzo de 1940, en dos semanas, entre los días 2 y el 17, Larrea se examinó de las siete asignaturas de Tercer Curso y sacó notable en cinco-Química, Genética, Motores y máquinas, Electrotecnia y Construcción-y aprobado en "Bioquímica y Microbiología" y en "Idioma alemán". En el mismo año, en octubre, hizo los exámenes de las seis asignaturas del Cuarto Curso, Química, Zootecnia, Hidráulica, con notable; "Herbicultura, Praticultura y Horticultura", "Arboricultura, Viticultura y Selvicultura" y Entomología agrícola, con aprobado. ¡En cuatro meses, dos cursos!

El curso siguiente parece tener más apariencia de normalidad, pero es dudoso que hubiese clases regladas. Larrea aprobó en junio de 1941 siete asignaturas, entre ellas Derecho administrativo, Contabilidad, Enología -en la que sacó un 8,10-, Patología General, Ingeniería sanitaria. La asignatura "Proyectos generales y especiales de ingeniería agronómica" la aprobó el 11 de octubre de ese mismo año, así como las que componían el "Trimestre complementario", a cuyos exámenes Larrea se presentó entre el 29 de septiembre y el 8 de octubre. Este "Trimestre" había consistido en cursar muy por encima las asignaturas -a juzgar por

22. Véase la reseña histórica que publica la actual Escuela en su web oficial: http://www. upm.es/ETSIAgronomos/Escuela/Historia/Rese\%C3\%B1a.

23. Algunos que habían sido las grandes cabezas que dirigieron la universidad, y en el mundo de la agricultura, los planes de modernización de la República, pasaron a ocupar oscuros destinos, como es el caso de don Pascual Carrión, que ocuparía el mismo cargo en la Estación Enológica de Requena que don Antonio Larrea en la de Haro. Carrión había sido uno de los técnicos de la reforma agraria republicana y un hombre de gran cultura, además de un gran ingeniero agrónomo, al que seguramente conoció Larrea en la Escuela. Véase Pan-Montojo, J. (2007), "Pascual Carrión: política agraria e ingeniería social", Historia Agraria, 42, pp. 581-596. 
el escaso tiempo que duró- "Parques y jardines", "Cultivos de plantas tropicales y medicinales", "Vías y transportes agrícolas" y "Agricultura comparada". Así, el día 11 de octubre de 1941, Larrea superaba la asignatura "Proyectos" para la que, firmando como "alumno n ${ }^{\circ} 16^{\prime \prime}{ }^{24}$ había realizado un trabajo titulado "Proyecto de Explotación agropecuaria en la provincia de Burgos". En papel de estraza gris, sin encuadernar, a pluma, Larrea escribió durante el verano de 1941 unas cuantas páginas que comenzaban por unas "Consideraciones generales" sobre la región -clima, geología, etc.- y sobre la finca en la que iba a desarrollar su proyecto. No olvidaba ni la situación legal de ésta, ni "la propiedad y el medio social, el crédito y el comercio, las comunicaciones y transportes", etc. de la región. Pero sobre todo, destacan sus dibujos de las "casas para obreros", firmados en "Burgos, julio de 1941" que denotan ya su preocupación por la situación social. En aquella estructura asfixiante que el Régimen estaba recreando, las casas dibujadas por Larrea, de planta baja, prototipo de las Ilamadas entonces "casas baratas" - de las que hay ejemplos en las planificadas en Logroño o, más tarde, del barrio de Yagüe, por ejemplo-, tenían tres dormitorios, cocina y un gran corral, una mitad era casa, la otra, corral, clave para la subsistencia por la cría de gallinas y conejos. El proyecto y los dibujos fueron guardados por Larrea entre las páginas de un ejemplar del ABC de 20 de agosto de 1941, precisamente en las que se daba cuenta del victorioso avance del ejército alemán hacia San Petersburgo y de los duros bombardeos de Odesa por el Reich. ${ }^{25}$

Así pues, Larrea terminó la carrera ese día 11 de octubre de 1941, cuando entregó el proyecto de su "explotación en Burgos" y pasó a ser uno de los 36 de la promoción 81 de la histórica Escuela. Su nota media era 6,583, lo que le situaba en el número 17 de su orden promocional. El título profesional de Ingeniero Agrónomo le fue expedido en fecha 30 de diciembre de $1946 .{ }^{26}$ Entre finales de 1941 y principios de 1943 se benefició de cuatro becas ${ }^{27}$ e ingresó en el Cuerpo Especial de Ingenieros Agrónomos el 10 de abril de 1943. Según el Anuario de 1980, en su página 296, editado por el Consejo Superior de Colegios Oficiales de Ingenieros Agrónomos, Larrea figura como colegiado número 68 del Colegio Oficial de Ingenieros Agrónomos de Zaragoza, que incluía la provincia de Logroño.

Antes de recalar en EVE Haro, Antonio Larrea estuvo destinado en Palencia, de junio de 1943 a octubre de 1944, tierra en la que vivía con sus padres desde su niñez. Desde ahí se trasladó a Haro, a su primer destino, la famosa Estación de Viticultura y Enología creada en 1892, a la que iba a entregar 26 años de su vida, sin duda, los mejores, los que le permitieron aprender, enseñar, formar a los

24. Expediente personal de Antonio Larrea, amablemente facilitado por la Escuela Técnica Superior de Ingenieros Agrónomos de la Universidad Politécnica de Madrid.

25. FL Vivanco, caja 29.

26. Expediente académico de Larrea.

27. Currículum vitae de Antonio Larrea escrito por el propio Antonio Larrea, cedido por su sobrina, Amparo Larrea. 
mejores enólogos de La Rioja -y de otras denominaciones-, investigar y experimentar, publicar y preparar su doctorado, que le será reconocido en 1961, ${ }^{28}$ pero también forjar su carácter junto a las gentes de Haro, enamorarse de la ciudad, escribir sobre su historia y tomar una de las grandes decisiones de la vida: casarse. Larrea contrajo matrimonio el 10 de febrero de 1947 con Julia Caño Aguirre, quien se convertiría en su inseparable compañera hasta su muerte en 1984, doce años antes que él, que falleció el 19 de marzo de 1996. ${ }^{29}$

Don Antonio Larrea Redondo constituye, en sí mismo y en su obra y trayectoria, un espejo modélico de los grandes hombres del Rioja, como lo fueron, y lo son, los bodegueros, los viticultores, los enólogos o los investigadores. Es un espejo modélico de un tipo de hombre para una etapa decisiva de trasformación, como decimos.

Para Ruiz Hernández, su principal discípulo, Larrea marcó el cauce para ayudar a los agricultores y propiciar su regeneración. Al no haber capitalización, solo se podía ayudar a los agricultores si antes se ayudaba a las bodegas, tarea que asumió muy consciente. Como regeneracionista, Larrea se esforzó en desarrollar la enseñanza sobre todo lo demás, y resistió los reveses que iba sufriendo en su actividad, pues a la desaparición de los cursos en 1964, le siguieron las desapariciones de los campos de experiencias y de la bodega experimental después. Aun así, trató siempre de vivir su profesión como una aventura. Ruiz reflexiona que "cuando no se tiene otra cosa que el pensamiento y la profesión, ambas cosas se constituyen como el único patrimonio. Por lo que nunca debe uno permitir que le corten el acceso al conocimiento". Máxima que aprendió de Larrea. ${ }^{30}$

Para De Jaime Baró, "tocó a Antonio Larrea tutelar, desde sus puestos de director de la Estación Enológica y presidente del Consejo Regulador, el despertar de nuestra vitivinicultura y nuestra Denominación de Origen a la época moderna. Desde aquellos años cincuenta en que la comercialización de nuestro vino comenzaba a despertar con los primeros intentos de exportación significativa y el paulatino desarrollo de nuestros vinos embotellados, hasta finales de los años 60 en que se crearon las grandes empresas bodegueras riojanas, se consolidaron las bodegas tradicionales, se expansionó el cooperativismo vinícola y comenzó la promoción de nuestros vinos, Antonio Larrea llevó con espíritu conciliador el timón del Consejo Regulador en singladuras a veces tormentosas (¿cuándo no?), consiguiéndose en esa etapa avances significativos que cimentaron éxitos posteriores. En lo que respecta a nuestra vitivinicultura, su labor como divulgador,

28. El 4 de mayo de 1961 se le reconoció el grado de "Doctor Ingeniero", de acuerdo a la legislación de 1957, que permitía obtener este grado "mediante la aportación de los méritos y circunstancias individuales en los órdenes académico y profesional y la presentación de una tesis, que podrá consistir en un trabajo original anteriormente realizado", que en el caso de Larrea, fue, entre otros, Vides americanas portainjertos. Información facilitada por la Secretaría del Director de la ETS de Ingenieros Agrónomos de la UPM.

29. Agradecemos una vez más la documentación proporcionada por la familia Larrea.

30. Entrevista con Manuel Ruiz Hernández, 30 de diciembre 2013. 
con libros ya clásicos como Vides americanas portainjertos y Vides de Rioja en su entorno, ha representado una aportación fundamental en momentos de escasez en la didáctica vitícola nacional. Destaca igualmente su trabajo de revitalización, en su momento, de las actividades de ensayos y análisis en la Estación Enológica, mejorando laboratorios y campos de experiencias, y formando y dirigiendo equipos técnicos de gran valía profesional. Pero quizá su actividad más querida fue la enseñanza vitivinícola, reanudando en la Estación los estudios de capacitación en viticultura y enología, en los que supo desarrollar con plenitud sus capacidades pedagógicas y humanas. Los técnicos de toda una época de la vitivinicultura española recibieron su magisterio, pues de toda España acudían a formarse alumnos a la Estación Enológica de Haro. La organización y dignificación de la profesión mereció también sus esfuerzos, siendo decisiva su intervención en la fundación y desarrollo de la Asociación Nacional de Enólogos. Como articulista y divulgador realizó una ingente labor...". ${ }^{31}$

Y es que Larrea fue ingeniero, director de la Enológica, presidente del Consejo Regulador, investigador, fundador de la Asociación Nacional de Enólogos, divulgador y maestro de viticultores y enólogos, hombre de la cultura en el IER y en la Casa de Cultura de Haro, un pensador sobre el agro español y el Rioja, un historiador, articulista y poeta, un erudito al fin, preso de la vocación de la que habla Javier Gomá Lanzón: "La vocación constituye una anomalía vital y un objetivo empobrecimiento: supone la activación de todas las facultades, capacidades y potencias humanas en la dirección de una -una sola- de las muchas posibilidades que ofrece la exuberancia vital; a cambio, una inmensa concentración de energías". ${ }^{32}$ Una concentración de energías que permitió contar a nuestra región y al Rioja con un alma durante esas décadas decisivas y transformadoras, las que vieron la reconstrucción, evolución y consolidación del sector Rioja como un modelo social y económico vitivinícola de éxito y prestigio internacional.

\section{La modernización científica. La Enológica}

"Útil a la sociedad", eso tenía que ser la Enológica y Larrea tenía que conseguirlo. Según Larrea, el concepto de Estación Agraria partía del siguiente axioma: "cuando era necesario en nuestro país adquirir el conocimiento de una realidad comarcal, o difundir unas prácticas agrícolas determinadas, se disponía de un equipo técnico, con el material adecuado se situase -hiciese estación- en la comarca, hasta que se consiguiese el objetivo señalado. En ocasiones, por no estar muy definido el momento de conseguirse lo que se pretendía, el existir costosas instalaciones, u otras circunstancias, hacía que la Estación dejara de serlo para

31. "Antonio Larrea, maestro de la vitivinicultura riojana". Diario La Rioja, 20 de marzo de 1996, p. 19.

32. Gomá Lanzón, J. (2013), "Raptado por las musas", Babelia, El País, 17 de agosto de 2013. 
convertirse en Centro permanente." Y de ahí pasaba a la explicación histórica, según la cual, la creación de EVE respondió a tres objetivos: conocer, orientar y enseñar.

Conocer las descripciones de los portainjertos más usados en Rioja, la de las viníferas más importantes, estudios sobre casi todas las labores del viñedo, estudios de adaptación, de longevidad, de homologación de productos para viñedo, de marqueo, de variedades y prácticas de cultivo, estudios de los vinos que pueden obtenerse por cada variedad de uva, de mezclas convenientes y del tipo de vino de Rioja; también se realizaban estudios enológicos, tales como la definición del tipo de vino (recogida en la Enología de Riberau Gayon), la mezcla más conveniente para hacer vino de Rioja y prácticas de elaboración.

Orientar para mejorar, mediante consultas de los particulares, consultas verbales de las que no queda descripción -pero sí un cómputo día a día, que luego nos servirá para comprender cada época- , a pesar de que el protocolo lo exigía (sin embargo, algunos consultantes no deseaban aparecer en registro o documento alguno, porque aunque las consultas solían ser corrientes, el interesado temía una baja del precio de su vino si se conocía que había sometido el caldo a consulta). Fue sin embargo la que más se desarrolló, puesto que asesorar al agricultor o a la bodega era preferente siempre en la Estación. Había años en que se llegó a diez mil consultas y no sólo de Rioja, incluso de otros países. El control de muestras que entraban en el laboratorio era muy riguroso y el de consultas resueltas, en cambio, más aleatoria. Por cantidad de consultas recibidas, Logroño era el territorio central del origen de las consultas, y después Álava y Navarra, y de forma esporádica se recibían consultas de otras provincias españolas y también del extranjero. ${ }^{33}$

Enseñar era la obsesión del tiempo en que fue creada EVE, por eso la enseñanza arrancó en el primer año de vida de la Estación, siendo el de 1892-1893 el primer curso de año completo. La carrera de dos años se impartió, con altibajos, en el periodo comprendido entre 1892 y 1936 . Hasta 1936 el título que se obtenía era el de Aprendiz y al final del segundo año de estudios se alcanzaba el título de Maestro Bodeguero, ambos certificados y otorgados por la Dirección General de Capacitación. Tras la guerra y la larga posguerra, se reanudaron los cursos en el 1946, estructurados en tres meses intensivos (70 días lectivos), mañana y tarde con lecciones diarias de todas las asignaturas y prácticas también diarias, de tal forma que equivalían al año completo de la antigua enseñanza (ocho meses corrientes con asignaturas alternas). Al exigirse estudios previos para ingresar

33. AEVEH, memorias de varios años. También Pascual Corral, J. y León Sáenz, J. (coords.) (1992), 1892-1992. Estación Enológica de Haro, cien años de historia. Gobierno de La Rioja, Consejería de Agricultura y Desarrollo Rural, Logroño; De la Fuente Rosales, F. (2011), Temas Jarreros II, "Capítulo 7. La Estación Enológica", pp. 321-393. Ayuntamiento de Haro, Haro; Egido, A. (2005), La Estación Enológica de Haro. Un referente para la ciencia y la técnica del vino desde 1892. Ediciones La prensa del Rioja, Logroño. 
(conocimientos de cultura general y matemáticas que debían demostrarse en un examen de ingreso), las enseñanzas fueron prácticamente las mismas.

Desde 1948 también se impartieron varios cursos monográficos que versaban sobre asuntos concretos como la poda, el injerto o la elaboración de vinos. Duraban ocho días, seis lectivos, los alumnos eran becarios y eran organizados y financiados por la Cámara Oficial Sindical Agraria, que recibía el visto bueno anual de la Dirección General de Capacitación, que era quien aprobaba el proyecto. También se realizaban cursos de tres meses monográficos que organizaba y desarrollaba el Patronato de Promoción Profesional, PPO. Los mismos cursos se transformaban en ciclos de conferencias nocturnas, igualmente financiados y organizados por la Cámara Oficial Sindical Agraria, que en 1971 se trasladaron al Servicio de Extensión Agraria. También consta un curso de postgraduados en 1969, que luego se repitió, y que consistía en que un curso que se celebraba en Madrid pasaba tres días en La Rioja recorriéndola y teniendo coloquios con el personal del Centro. Otros estudiantes, dos en 1971, realizaban prácticas como laborantes voluntarios y ejercitaban en el Centro lo que la teoría les había mostrado en el aula.

También se llevaron a cabo conferencias, congresos y coloquios y se publicaban una media de diez monografías y treinta artículos a revistas y diarios al año. ${ }^{34}$

La actividad docente acabó en 1965, cuando se reorganizaron de nuevo las enseñanzas agrarias a través de una reordenación que emprendió la Dirección General de Capacitación, y EVE quedó fuera del sistema por no tener suficiente personal para dedicarlo a las tareas docentes.

En esos casi 30 años que van de 1936 hasta 1965, casi 1000 alumnos, 926, pasaron por las instalaciones de EVE formándose como aprendices y maestros bodegueros. ${ }^{35}$

Con todo, la principal actividad de EVE estuvo siempre ligada, por encima del resto, a la viticultura y a la enología. Por fases, de 1940 a 1945 la principal actividad fue el análisis de vinos en el laboratorio (marginalmente se hacían análisis de abonos, harinas y tierras hasta que se encargaron a otros laboratorios con el cambio de legislación interna por la que el laboratorio pasó a ocuparse en exclusiva de los vinos) ; de 1945 a 1960, ya con más personal, se incrementó la actividad y se pusieron al día los estudios sobre portainjertos y viníferas, se hicieron homologaciones de criptogamicidas e insecticidas, continuaron los estudios de tipificación de Rioja y se hicieron prácticas del uso de clarificantes. El control en laboratorio de los vinos exportados comenzó en 1947, sufriendo diversas modificaciones y la vinculación con el Consejo Regulador de la Denominación de Origen Rioja se produjo en 1954. A partir de ese año, el director de EVE era también

34. FL Vivanco, caja 111, memoria mecanografiada, 1971.

35. El total de alumnos fue de 916.726 presentados a exámenes y 441 aprobados. Colina Salazar, I., Capataces de viticultura y enología. Años 1893-1964, Estación de Viticultura y Enología de Haro, sin fecha, p. 16. 
el presidente del Consejo, lo que suministró una nueva faceta a la Estación: las relaciones públicas. En 1970, ya dentro del INIA, comenzaba una nueva etapa. ${ }^{36}$

\section{El desarrollo institucional: el Consejo Regulador}

Resucitó el Consejo Regulador justo cuando llegó Larrea a Haro. Estaban puestas ya las bases del desarrollo. ¿Qué faltaba, entonces? A una pregunta similar, como recoge el profesor Gómez Urdáñez, el cosechero de Laguardia, más conocido en el mundo literario, Félix de Samaniego, respondió "luces e instrucción". ¿Tendría esas luces Larrea? ¿Tendría esa instrucción el joven ingeniero al que la enfermedad y la guerra habían interrumpido su carrera? ¿Sería sólo eso lo necesario cuando el Régimen parecía no tener fin? Por si acaso, Larrea iba a encontrar delante al Sindicato, a la Falange, que había fundado la delegación provincial del Sindicato Nacional de la Vid y el Vino el 1 de enero de 1941 en Rioja, un organismo que encuadraba a todo el sector y a todas sus instituciones, incluida la Enológica y el Consejo Regulador, bajo el mando del Jefe Provincial, Víctor Pérez y Díaz de Mendívil, gerente muchos años de la bodega CVNE, luego sustituido por Marcelo Frías Artacho, el que tanta relación tuvo con Larrea en todos los organismos. Hombres duros, profundamente falangistas, que contrastaban en tantos aspectos -incluso de la vida diaria- con Antonio Larrea, hombre humilde, tímido y exento de cualquier vicio, en comparación con estos hombres fuertes y dominantes. Como leemos en El Rioja histórico, en 1949, cuando hacía dos años que se había aprobado el reglamento por el que renacía el Consejo Regulador de la Denominación de Origen Rioja, los Criadores-Exportadores volvían a demostrar quién mandaba y reivindicaban la autonomía del Sindicato Provincial de la Vid nada menos que para "controlar el uso de marcas colectivas y denominaciones de origen". Eran 24 empresas las que conformaban el subgrupo de Criadores-Exportadores en los años cuarenta y por tanto, imponían su dictado en las provincias de Logroño, Álava, Burgos y parte de la de Navarra, y para el subsector específico de la exportación, en toda la zona norte de España, comprendiendo Aragón, Rioja y Navarra, con capitalidad en Logroño. En esas circunstancias, bajo el control absoluto de Falange, renacía -de iure- el Consejo Regulador, que en 1947 se dotaba de un nuevo reglamento. ${ }^{37}$ La realidad imponía que un hombre como Larrea se hallara al frente, de manera obligada, un hombre que nunca hubiera querido estar ahí, pero que quizás precisamente por eso, supo hacer -incluso no haciendo-que esos hombres fuertes se entendieran con los empobrecidos viticultores y renaciera el "pacto entre desiguales", al que debemos que el Rioja siga siendo el resultado de aquel cultivo social y poblador.

¿Cómo iba a funcionar un organismo amparado por una legislación que no definía quién controlaría al controlador? ¿Qué iba a hacer un presidente entre los

36. FL Vivanco, caja 111, memoria mecanografiada, 1971.

37. El Rioja histórico..., pp. 100-109. 
grandes bodegueros organizados, que eran los que ponían el dinero, y los viticultores, dependientes, por mucho que se organizaran en cooperativas? ¿Cómo se podía defender la marca Rioja cuando los grandes bodegueros riojanos tenían viñas y bodegas en Cariñena, en Castilla o en Mancha y siempre habían utilizado la marca "Rioja" en su beneficio? Eso es lo que debió pensar Larrea cuando el 12 de julio de 1953 tuvo que "bajar a Logroño" para constituir como presidente el Consejo Regulador de la Denominación de Origen Rioja. ${ }^{38}$ Poca confianza podía tener ante la nueva tentativa, que ya había renacido sobre el papel unos años antes. Larrea dice en un boletín de 1952 que en otras zonas se van creando ya los Consejos según la nueva ley; pero "aquí solo se acuerdan de Santa Bárbara cuando truena", 39 aunque ya estaba tronando, es decir, se abrían los mercados, aumentaba la exportación y los bodegueros riojanos volvían a necesitar la marca Rioja (aunque luego trajeran uva y vino de cualquier procedencia). Como veremos en el capítulo siguiente, el Consejo Regulador ya había fracasado en 1947 a causa de la poderosa oposición de los grandes, amparados por el Sindicato Nacional de la Vid y el Vino, y el marco legal volvía a darles a ellos todo el poder. ¿Qué hacer para que de nuevo no fuera un "organismo inoperante"?

Como concluía drásticamente Larrea en su informe de 21 de julio de 1948, en "Propuestas de Solución", "el Consejo Regulador de la región Rioja no existe (subrayado en el original) desde el momento que no se ha acogido a su protección ninguna bodega dentro del plazo oportuno, y si la inscripción era obligatoria, carece de medios coercitivos para obligar Ilevar a cabo la citada inscripción" ${ }^{40}$

En paralelo a esta defunción, sin embargo, el Sindicato Provincial gozaba de muy buena salud, como se puede comprobar por el monto de sus actividades de esos años. Como en todos los demás ramos, todo pasaba por el Sindicato (o por los Servicios Nacionales, como el Servicio Nacional del Trigo), es decir, por Falange, constituida en la columna vertebral de la vida económica y social todavía a fines de los cuarenta.

Pero ya conocemos a Larrea: nunca va plantear la lucha abierta, ni se va a sumar a ninguno de los bandos contendientes, ni se va "posicionar" ideológicamente. ${ }^{41}$ Por eso, mientras la situación política y económica y la coyuntura internacional no se definan en beneficio del Rioja y se necesite de nuevo el Consejo Regulador, la labor de Larrea vuelve a ser su Enológica.

La siguiente tentativa de resucitar el Consejo Regulador se produjo al amparo de la decisión ministerial de reformar el reglamento, que fue aprobado el 16 de

38. AHCR. Actas, sesión de 12 de julio de 1953 y ss. Hay copia de las actas del Consejo, guardadas por Larrea, en FL Vivanco, caja 18.

39. FL Vivanco, caja 57.

40. FL Vivanco, caja 18.

41. Así se lo dice, expresamente, a Pérez y Díaz de Mendívil en la carta de 4 de febrero de 1948: "espero que comprenderá usted mi posición, pues soy funcionario y por tanto, no me puedo poner rotundamente al lado de nadie". FL Vivanco, caja 18. 
abril de 1953 y publicado en el BOE el 23 de junio. El nuevo reglamento, que seguía manteniendo la presidencia en el ingeniero director de la Enológica, introducía cambios sustanciales que, de entrada, iban a permitir al Consejo Regulador iniciar la consolidación institucional, aunque fuera muy tímidamente todavía frente al Sindicato. La reforma regulaba los distintos registros necesarios para una eficaz vigilancia $y$, sobre todo, intensificaba las medidas de control en algunos aspectos básicos. Los precintos con la marca de la Denominación serían repartidos exclusivamente por el Consejo, siguiendo las directrices del Ministerio de Hacienda. Pero lo más importante era que el reglamento abría la posibilidad de que el Consejo Regulador contara con veedores propios para vigilar el cumplimiento de sus fines. Dependerían del Ministerio de Agricultura, pero la propuesta de nombramiento de veedores la efectuaba el Consejo, que corría con los gastos derivados de su actuación, a decir verdad, bien escasos. También es cierto que el número de veedores será tan escaso que veremos a Larrea alegrarse cuando se contrata jun veedor más! ${ }^{42}$

A pesar de las buenas intenciones del reglamento del 53, seguía existiendo la insalvable contradicción: el Consejo carecía de una financiación adecuada para hacer frente a sus cometidos; además, a partir de ahora, se recortaban sus ingresos al acordarse la reducción del canon pagado por las bodegas en 50 céntimos menos por hectolitro en el vino destinado a la exportación y en 1,15 pesetas en el hectolitro que se vendía en el interior. ${ }^{43}$ La situación no permitía albergar muchas esperanzas, así que el presidente Larrea no podrá tenerlas en algunos años.

No es éste el lugar para volver sobre un aspecto muy conocido, gracias a los trabajos de los profesores Carlos Coello y Emilio Barco y al pionero de Gómez Urdáñez, pero sí vamos a intentar verlo con los ojos de Antonio Larrea, tanto a través de la actas, conservadas en su archivo personal, hoy Fondo Larrea en el Centro de Documentación de la Fundación Vivanco de la Cultura del Vino, y en el archivo del Consejo Regulador de la DOC Rioja, como a través de sucintas notas que añadió, año a año, a la memoria anual de la Enológica. De toda esta documentación se desprende que Larrea "bajaba" a Logroño con muy poco optimismo, pues la normativa legal no acababa de aclararse y el Consejo seguía teniendo muy pocas armas contra fraudes y abusos. Es cierto que en 1953 algo parecía haber cambiado, pero pronto se impondría la realidad, lo que el presidente sospechó desde el primer día. Había constituido el Consejo en julio de 1953 y en diciembre se despachaba con un artículo en el diario Nueva Rioja que seguramente fue severamente juzgado por algunos bodegueros. Desilusionado y todavía inexperto, Larrea también se dejaba llevar por la inercia de la época y podía llegar a escribir lo siguiente para explicar por qué todavía no se había puesto en funcionamiento el Consejo Regulador de La Rioja y se respondía:

42. El Rioja histórico..., p. 110 y ss.

43. Coello Martín, C. (2008), El Rioja histórico (2000). 
por dos razones, las dos dependiendo de malas cualidades del pueblo español, que las tiene, ya que no todo van a ser virtudes y buenas cualidades. La primera, la rebeldía innata del español a todo lo que suponga organización, disciplina, colaboración. Cree el labrador que haciendo las cosas aislado, sin apoyarse en otros, sin presentar un frente único, le va mejor y que así no le explotarán, no le engañarán; las consecuencias suelen ser fatales: no le engañan los empleados del estado, pero sí los almacenistas y comerciantes de toda índole. La segunda es el espíritu de picaresca que todo español tiene un poco metido en el cuerpo ilmpedirle al elaborador sus pequeños trapicheos? ¿Obligarle a que todo el vino sea de buena calidad y que si sale algo malo, estropeado, con mal olor o sabor, no intente colarlo con lo bueno? Imposible. El labrador ha de tener las manos libres. Y las consecuencias se van viendo: el bajón más brutal de precios ha sido el del precio del vino; y vienen las súplicas y el poner precipitadamente en funcionamiento Consejos Reguladores y las medidas de protección y el solicitar que hasta las niñas de los colegios se les haga beber vino. Antes debieran haberse hecho las cosas. ${ }^{44}$

Así pues, el 12 de julio de 1953, Antonio Larrea constituyó el Consejo Regulador advirtiendo que la reunión tenía carácter de extraordinaria "puesto que al no funcionar normalmente el Consejo no hubo fundamento suficiente para entrar en un periodo normal de convocatorias". ${ }^{45}$ Estaban en la reunión Jesús Jiménez Sáinz de Rozas (presidente de la C.O.S.A.), Cándido Ochoa Calahorra, Jesús Santiago Calleja, Rafael López de Heredia, Víctor Pérez Díaz de Mendívil y el que ya actúa como secretario Enrique del Río Villarejo, que lo es también del Sindicato. Se trataba antes de nada de implantar el reglamento que el Ministerio de Agricultura había publicado en el BOE el día 23 de junio y que afectaba a Criadores-Exportadores pero también a viticultores, a los que se convocará a través de la C.O.S.A. y de las hermandades de Labradores. Los secretarios de las hermandades actuarán como agentes del Consejo Regulador, mientras Sáinz de Rozas y Ochoa Calahorra son delegados para que "establezcan el procedimiento más eficaz" para que los viticultores conozcan los objetivos del Consejo.

\section{Un programa para el Rioja}

Larrea tuvo siempre en su cabeza un programa, un proyecto para el Rioja. Por vez primera y de forma detallada, lo expuso en el I Congreso Económico Sindical, celebrado en febrero de 1962, al que presenta la ponencia titulada "Es-

44. Publicado en Nueva Rioja, diciembre de 1953, recorte en AEVEH, memoria de 1953, caja 1095.

45. ACRDOC Rioja, Actas, acta de los días señalados. 
tado actual de la vitivinicultura logroñesa y posibilidades futuras", ${ }^{46}$ un trabajo de madurez, en el que vierte y analiza las preocupaciones que en el sector Rioja serían una constante durante esa década: la productividad, las variedades, la concentración parcelaria, la formación de los agricultores y el nivel de vida de los "trabajadores del campo", la "estabilidad de los productos del campo", los precios finales al consumo y, cómo no, la repercusión para la venta de vino y uva español una vez que España se incorporase al Mercado Común, toda vez que ya habían comenzado las negociaciones para la misma un año antes, en 1961..77 Para Larrea todo se reducía a: "Productividad mayor y precio internacional", con el siguiente diagnóstico: "tierras muy divididas y dispersas que demandarían una concentración", por tanto, primero la parcelaria y después las "unidades cooperativas de cultivos (comunidades de productores)"; exceso de impuestos, sobre todo el transitorio; mecanización de la labor del cultivo en las plantaciones y replantaciones para dar entrada a los portainjertos e "intensificando al máximo la colocación de variedades blancas" que mejorarían la productividad, abaratarían la producción de vino blanco y "abrirían nuevas posibilidades a la exportación". 48

Larrea resumía así su ponencia: "Propugnamos una racionalización del cultivo de la vid, reformando su estructura, mecanizando el cultivo y acostumbrando al cultivador a usar sin miedo fórmulas científicas de abonado y tratamientos", y planteaba cinco conclusiones, que en realidad eran cinco propuestas concretas, casi un programa de reformas y mejoras: la supresión del impuesto transitorio, ${ }^{49}$ la creación de una Subestación de Viticultura y Enología en Calahorra dependiente de la de Haro, "para atender al sector vitícola de Rioja Baja, muy importante y numeroso", la creación de campos de experiencias en puntos estratégicos durante diez años, una simplificación administrativa en lo referente a las solicitudes de plantaciones y replantaciones que afectaba a los organismos oficiales provinciales, y, por último, el encargo que hacía a la Cámara Oficial Sindical

46. I Congreso Económico Sindical. Subponencia de Vitivinicultura y Enología. Posibilidades futuras de la Vitivinicultura Logroñesa. AEVEH, memoria de 1962, caja 1097.

47. La primera solicitud de España la firma el ministro Fernando María Castiella el 9 de febrero de 1962. Es una carta dirigida al presidente del Consejo de Ministros de la CEE, Couve de Murville, que se limitó a contestar con un mero acuse de recibo un mes después. Dos años después, el 14 de febrero, el embajador español ante la CEE, conde de Casa Miranda, recordó la solicitud y esta vez, la CEE formó una Comisión para estudiar el caso español, en el que, aunque Franco lo ocultara, el gran problema era el carácter no democrático del Régimen. Véase La Porte, M. ${ }^{a}$ Teresa (1992), La política europea del Régimen de Franco, 1957-1962, Pamplona, EUNSA. Con carácter general, Tusell, J., Aviles, J. y Pardo, R. (2000), La política exterior de España en el siglo XX, Madrid, UNED/Biblioteca Nueva; y Tió Saralegui, C. (1986), La integración de la agricultura española en la Comunidad Europea. Mundi Prensa Libros.

48. I Congreso Económico Sindical. Subponencia de Vitivinicultura y Enología. Posibilidades futuras de la Vitivinicultura Logroñesa. AEVEH, memoria de 1962, caja 1097.

49. Se refería al impuesto transitorio sobre los viñedos, recurso institucional establecido por Decreto-Ley de 10 de agosto de 1954 y confirmado en la Orden de 27 de diciembre de 1966 por la que se aprueba la "Instrucción provisional de administración y contabilidad de los recursos locales e institucionales administrados por la Hacienda Pública". 
Agraria para que elaborase un plan concreto de formación de cosecheros, con campañas anuales y cursillos. Todavía hoy, los defensores del Rioja firmarían esta planificación.

La visión social del campo, tan constante en Larrea, fruto de su visión social general, y en particular de la doctrina social de la Iglesia, tan presente en sus escritos cuando cita la encíclica Pacem in terris de Juan XXIII, encontrará un lugar reiterado en sus artículos, y en especial en el publicado en "La Semana Vitivinícola" de julio-septiembre de $1964 .{ }^{50}$ Larrea defenderá de nuevo la concentración parcelaria "para reunir en la mano del propietario, en el menor número de fincas posible, sus propiedades"; y la cooperación, "para lograr fincas en las cuales sea rentable la mecanización, es decir, el uso de maquinarias, abonos, etc.". Y es que piensa que "la excesiva división de las tierras de España es una causa muy extendida". Unido a esto, seguirá mostrando su preocupación por la calidad del vino, ${ }^{51}$ porque "no se puede cultivar de cualquier manera, sino pensando en los gustos de los futuros consumidores", y por la vida del agricultor y del cosechero, porque "para que se deslice por cauces más apetecibles que los actuales, es necesario que concentre sus viñedos, que los explote en comunidad con otros, que procure, mediante las adecuadas labores de cultivo, un aumento de la calidad". De igual forma, defenderá que el agricultor se implique en la transformación del producto y en la comercialización, que reconocerá "no está al alcance de los agricultores aislados", para después afirmar "la necesidad de que se unan formando cooperativas de comercialización".

Larrea, finalmente, muy consciente de la situación precaria y débil de los agricultores planteará un programa para la mejora en la calidad de sus vidas, basado en la autonomía y en la cooperación. Programa muy conciso, pues "el camino está claro. Tenemos el agricultor, que reúne sus uvas en vendimia. No debe venderlas, sino vinificarlas por sí mismo en una gran cooperativa (no es aconsejable la vinificación individual)". De una forma valiente, alienta un espíritu de reclamación en los cultivadores, cuando aconseja "hacer la suficiente presión, a través de cauces sindicales, para que se fije un precio justo de la uva o del vino y no dependa de caprichos de compradores". ${ }^{52}$ Sigue, animando a "tener cooperativas de segundo grado con red comercial y no estar a la expectativa de cuándo querrá entrar por la carretera de su pueblo, sin arreglar la mayor parte de

50. Ver "Hacia la promoción de la viticultura española", en La Semana Vitivinícola bajo el título "Temas vitivinícolas de actualidad", números 936-37, 938, 940, 942, 946, julio-septiembre de 1964, Valencia.

51. Calidad, que según Larrea "comienza en el cultivo de la vid. Y sigue en la recolección. Y se hace culminante en la elaboración". Ídem.

52. Como hará en otros artículos, como por ejemplo en el publicado en La Gaceta del Norte el 20 de agosto de 1969, cuando escribirá en un artículo titulado "Protestas generales por el precio de vino, en Rioja", que existe una "eterna lucha entre los precios de la venta al público de los productos agrícolas, siempre muy congelados, y los precios que necesitaría el productor que se le pagasen, de acuerdo con la elevación del nivel de vida, con los aumentos de precio de los abonos, gasolina, tarifas, maquinaria, tractores y demás". 
las veces, un posible comprador". La máxima autoridad del Consejo Regulador de Origen Rioja, su presidente, preconizará por último "un cambio total de mentalidad: de individualismo a cooperación, de desconfianza en la técnica a dejar todo en manos de la técnica, de no ocuparse más que de producir, a pensar en los complejos asuntos de la tipificación, envasado (...)", y rematará asentándose en los viejos pero novedosos principios del liberalismo capitalista, sorpresivos e incluso agresivos, para un país hasta hace una década sumido en la autarquía cuando dice: "el Estado solo debe acudir donde la iniciativa particular no pueda salir adelante por sí misma". Está claro que su pensamiento distaba mucho del falangismo que animaba a muchos de los Criadores-Exportadores, que veían en el Estado totalitario la solución, siempre de arriba abajo. ${ }^{53}$

En otro de sus últimos viajes como director fue a Valladolid, invitado por el Colegio Oficial de Ingenieros, para que pronunciara una conferencia que tituló "Vinos de Castilla". ${ }^{54} \mathrm{Al}$ final de la conferencia, respondía al gran interrogante del porvenir en el campo, sobre todo en el mundo del vino, que como ya sabemos atravesaba una situación crítica y paradójica: grandes rentabilidades en la comercialización y cada vez menos en el hombre del campo. La solución de Larrea era triple: propaganda, protección de la Denominación y exportación al extranjero. Un cuarto de siglo después el Ingeniero experimentado en todas las lides de la cultura del vino, acababa como empezó: la propaganda era lo que él llamó "apostolado", solo que ahora "se vivía en una civilización de consumo"; la protección de la Denominación era lo que él había hecho por partida doble, en la Enológica y en el Consejo Regulador; y la exportación al extranjero, su gran logro personal, ahora además estaba privilegiada tanto por el Gobierno como por la Comunidad Europea.

\section{La conquista del mercado exterior}

Los hombres del Rioja siempre supieron que vender fuera era la única posibilidad de confirmar al vino como un negocio de éxito, como un producto expansivo y firme, que debía transformase, paulatinamente pero sin descanso, en un mercado en sí mismo, el del Rioja dentro del más amplio del vino en el mundo. No era una vía más, era el camino, incluso el motor que tiraría del conjunto. Por eso, la evolución desde los años cuarenta hasta la década clave de los sesenta, la de consolidación del mercado exterior del Rioja, es espectacular en este sentido. Así, si en 1946 se vendieron 21.097 litros de granel y 126.617 litros embotellados, 147.696 litros en total, por valor de 1.058.072 pesetas, en 1963 los datos eran

53. El ideario del Sindicato, en AHPLR, Fondo AISS, caja 585. Ver también Ortiz Rodríguez, José Luis (2000), "El Sindicato Nacional de la Vid", en Maldonado Rosso, Javier y Ramos Santana, Alberto, Actas del I Encuentro de Historiadores de la Vitivinicultura Española, Puerto de Santa María.

54. Ídem. 
los siguientes: 2.903 .835 litros de granel, 809.652 litros embotellados, 3.713.487 litros en total, y por un valor de 48.913 .184 pesetas. ${ }^{55}$ La evolución, como se ha dicho, era imparable, y no solo asombra en su comparativa con respecto a los años cuarenta, sino con un año respecto con el anterior. Por ejemplo, si en 1962 se habían exportado 1.433.215 litros, contando los graneles más los embotellados, por un valor de 12.720 .826 pesetas, al año siguiente, 1963, se exportarían 3.713.487 litros por un valor de 48.913 .184 pesetas; es decir, un incremento del $260 \%$ en cuanto a litros exportados, y un aumento del $385 \%$ de su valor. ${ }^{56}$ Pero este salto era menor si lo comparamos con el que se dio al año siguiente, 1964, cuando se vendieron al exterior 21.473.184 litros por un valor de 205.658.170 pesetas, año en que la cosecha alcanzó un total de 1.100 .000 de hectolitros. ${ }^{57}$

En esa década de los sesenta es cuando se puede ver la consolidación de unas bodegas que harán de la exportación su principal objetivo, como venían haciendo desde los años veinte. Bilbaínas, Entrena, Franco Españolas, G. Cruzado, Lagunilla, Las Veras, Montecillo, Bodegas Riojanas, Rioja Santiago, Romeral, Carlos Serres Hijo, Compañía Vinícola del Norte de España, Federico Paternina, La Rioja Alta, Martínez Lacuesta, Riscal, López de Heredia, AGE (Azpilicueta, García y Entrena), Marqués de Murrieta y SAVIN eran ya las grandes bodegas exportadoras que estaban configuradas para entonces como las más fuertes, ${ }^{58}$ y seguirán influyendo en toda la política exportadora de Rioja, un sector que ya estaba preparado para dirigirse a su principal y más codiciado nicho de mercado: los Estados Unidos de América.

En 1966, año de la primera misión a EEUU, España tenía relaciones comerciales con 56 países, ${ }^{59}$ gracias, por ejemplo, a las medidas liberalizadoras que algunos países como Brasil estaban introduciendo, como la reducción de los aranceles o la eliminación de la categoría especial, lo que permitió que España exportase vi-

55. AHPLR, Fondo AISS, caja 585. Desarrollo comparativo de las exportaciones de vinos Rioja realizadas durante el mes de noviembre del último quinquenio en relación con el mismo periodo de 1946.

56. AHPLR, Fondo AISS, caja 585. Estado comparativo de las cantidades y valoración de los vinos exportados durante los periodos que se indican. Sindicato Oficial de CriadoresExportadores de vinos Rioja.

57. AHPLR, Fondo AISS, caja 585. Datos sobre exportaciones de Vinos de Rioja. Cabe destacar la siguiente información recogida en el informe: "Presenta baja importante con relación a 1964 (se referirá a 1963) el mercado de Cuba, que no es compensada totalmente por los incrementos que registran otros destinos, entre ellos Venezuela".

58. AHPLR, Fondo AISS, caja 585. Resumen de las exportaciones y su valoración, realizadas por los miembros del Subgrupo de Criadores-Exportadores de Vinos durante el quinquenio 1960-1964 y promedios resultantes, y también Valoración de las exportaciones de Vinos Rioja en los años 1966 y 1967.

59. AHPLR, Fondo AISS, caja 585. Carta dirigida por Enrique Barceló Carles, presidente del Sindicato Nacional de la Vid, Cervezas y Bebidas, al Grupo de Exportadores en la que da cuenta del régimen contractual en materia de comercio exterior, vigente en España en 20 de enero de 1966. Sobre la exportación de vino español a Estados Unidos desde los años 40, véase FL Vivanco, caja 59. 
nos, licores y champán a este país por valor de más de 77 millones de dólares. ${ }^{60}$ En ese mismo año, en los Estados Unidos, la Embajada española informaba al Sindicato de lo siguiente: "las grandes firmas norteamericanas importadoras de vinos y licores prevén para el presente año de 1966 un aumento de un 10\% a un $15 \%$ en las importaciones de Estados Unidos de estos productos". ${ }^{61}$ Los norteamericanos incrementaban su consumo de vino, las firmas importadoras incrementaban a su vez la publicidad, y "además, el aumento en el consumo de vinos importados se verá también favorecido indirectamente por las campañas de promociones para el consumo de vino producido en Estados Unidos que el Gobierno norteamericano viene fomentando últimamente", ${ }^{62}$ informaba Enrique Barceló a los exportadores riojanos. Y lo que era más importante, la previsión era que el incremento de importaciones se centrase "en los vinos de calidad y precio más bien elevado, debido al hecho de que los vinos de calidad inferior y precio reducido se verán más afectados por la competencia de los vinos producidos en Estados Unidos...". ${ }^{63}$ Las cosas empezaban a ir de cara con la ya superpotencia mundial, en 1964 España había exportado 566.902 galones por valor de 930.764 dólares y en 1965, 596.075 galones por valor de 1.041.384 dólares, ${ }^{64}$ y España ya era el quinto país exportador de vinos de mesa a Estados Unidos, mostrándose muy competitivo en calidad y precio, si bien Barceló lanzaba la siguiente advertencia: "no obstante, nuestras firmas exportadoras deben mejorar sensiblemente la presentación, tanto en la calidad de las botellas como en el etiquetado y acabado del taponado, que en general desmerecen claramente con los demás países exportadores" ${ }^{65}$ Los exportadores riojanos recibían ese último día de mayo de 1966 las noticias que estaban esperando, pues el ansiado mercado estadounidense parecía al fin al alcance de la mano, las firmas importadoras contaban con "vastos sistemas de distribución"66 y realizaban campañas de promoción, y además recibían los consejos y advertencias necesarias para adentrarse en el terreno y operar comercialmente: calidad, precio, presentación, volumen de suministro y una adecuada representación. Larrea lo había entendido todo a la perfección. Tal es así, que tras el primer viaje y en su calidad de presidente del Consejo Regulador se dirigirá al Subgrupo de Criadores-Exportadores de Vinos para llamar su atención sobre aquellos aspectos que debían mejorarse, como la planificación o la necesaria unidad de esfuerzos para centrar la propaganda en torno a una

60. AHPLR, Fondo AISS, caja 585. Información sobre las exportaciones de Vinos Españoles a Brasil durante el trienio 1964-1966 del Sindicato Nacional de la Vid, Cervezas y Bebidas.

61. AHPLR, Fondo AISS, caja 585. Carta dirigida por Enrique Barceló Carles, presidente del Sindicato Nacional de la Vid, Cervezas y Bebidas, al Grupo de Exportadores sobre las perspectivas de las importaciones en Estados Unidos de vinos y licores en 1966.

62. Ídem.

63. Ídem.

64. Ídem.

65. Îdem.

66. Ídem. 
"marca que ampare vino de calidad", con el objetivo de "alcanzar una notable expansión de nuestra exportación vinícola". ${ }^{67}$

Al fin, tras vencer todas las complicaciones se hizo el viaje a Nueva York. Entre las complicaciones no era menor la de la asistencia espiritual que no podía faltar a los viajeros. Para asegurarse que habría un servicio católico en aquel país que tanto iba a impresionar a Larrea por su "materialismo" y "falta de fe", nuestro presidente escribió al párroco de una iglesia de Nueva York, José A. Valcárcel, quien inmediatamente se ofreció a acompañar a la legación riojana. ${ }^{68}$ Él mismo se personaría en el aeropuerto a esperarles. Como Larrea le había pedido que les alojara en establecimientos regidos por católicos, o en algún complejo religioso, el párroco les disuadió: "no les conviene debido a la distancia", respondió a Larrea, al que recomendó un hotel en las calles 30 a 52. Una vez en el hotel, que debía reservárselo el agente español de la entidad que organizaba el viaje, el párroco le indicaría la iglesia más cercana. Al final, el padre Valcárcel se sinceraba: "nuestra parroquia queda bastante lejos, a 20 minutos en el metro, pero es el barrio negro de Harlem, lo que me decide a no invitarles". ${ }^{69}$

Así pues, con asistencia espiritual y todos los detalles de organización a cargo de una agencia $-y$ la compañía de Julia Caño- ${ }^{70}$ los riojanos Ilegaron a Nueva York, donde permanecieron del 11 al 19 de agosto de 1966, inmersos en los numerosos actos que hubo en la célebre exposición de Nueva York, un evento impulsado por el Centro Permanente de la Oficina Comercial que el Ministerio de Comercio inauguró en la Avenida Madison, y en la que estuvo al frente Fernando Escribano. El Ministerio mantuvo una Exposición permanente de productos españoles, entre los que estaban también el calzado, el textil, etc. Una verdadera fiebre española se difundió por el país, puesto que hubo diferentes ferias en ciudades norteamericanas impulsadas por comerciantes y hombres de negocios que visitaban la Feria de Nueva York.

No hacía falta ser un lince del marketing para saber que en este mundo del vino un precio bajo es muy mala publicidad y cuesta mucho levantar sus perniciosas consecuencias, que es lo que le ocurría al vino español en USA y lo primero que iban a comprobar los riojanos, con Larrea al frente. Y ahí estaba el dilema: Larrea había dicho siempre que había que levantar primero el prestigio del vino español, pero ahora se daba cuenta de que el Rioja era arrastrado por

67. AHPLR, Fondo AISS, caja 585. Acuerdo del Consejo Regulador de 17 de septiembre de 1966 dirigido por carta al presidente del Subgrupo de Criadores-Exportadores de Vinos el 29 de septiembre de 1966 sobre la promoción de vinos de Rioja en los Estados Unidos de Norteamérica.

68. FL Vivanco, caja 26.

69. FL Vivanco, caja 26. Carta manuscrita de Valcárcel a Larrea, 15 de julio de 1966.

70. Se conserva en el Fondo Larrea una Declaración de Julia Caño en la que informará que el motivo de su viaje era acompañar a la misión exportadora, que se pagaba los gastos y que regresaría a España "a la vez que dicha misión comercial en la que figura mi esposo". FL Vivanco, caja 26. 
la mala fama de otros vinos. Y más aún, que en USA, había ya algunos riojanos que luchaban por introducir su marca antes que la marca Rioja. Incluso, más aún, que el éxito que tenía, por ejemplo, la sangría de Bodegas Santiago de Haro, no lo tenía nadie. ¡Y vendía Sant'Gría!

La exposición de Nueva York causó una enorme impresión a los riojanos, representantes de 19 grandes bodegas riojanas, tales como Bilbaínas, Rioja Santiago -el más aclamado por su Sant'Gría-, Montecillo, Rafael López de Heredia, Martínez Lacuesta, Franco Españolas; también estuvo Ortigüela, director de SAVIN, representantes de Riscal, así como los grandes de Fuenmayor, Entrena, Azpilicueta y Cruz García, que iban a reforzar AGE con nuevas ideas, al calor de la expansión del negocio que vieron en Nueva York. ${ }^{71}$ Allí constataron que había que introducir muchos cambios en Rioja, pues era obvio que, como decía el redactor de La Gaceta del Norte, Gustavo Valverde, "Ios vinos españoles no conquistan América". Larrea ya se había dado cuenta de que para entrar en USA había que dejarse en casa "la chaqueta vieja del pensar antiguo"72, pero es que además hacía falta ni más ni menos que enseñar a los yanquis a beber vino. El poco Rioja que había entrado en Estados Unidos lo había hecho "como un vino de imitación francesa", lo que había perjudicado enormemente su prestigio. ${ }^{73}$ Ahora era el momento de diferenciar al Rioja pero también había llegado la hora de aumentar los controles de calidad "como se hace en Francia e Italia". Nada mejor podía leer Larrea para seguir manteniendo su lucha en la Enológica y en el Consejo, precisamente cuando al debatir sobre los controles de calidad, algunos grandes del Rioja manifestaban incluso su deseo de salirse de la Denominación.

Los objetivos del viaje eran globales, pues también las conservas de pescados y vegetales tenían su espacio, como otros productos españoles, pero lo que importaba era el estudio de las cadenas de distribución norteamericanas para "acoplar nuestras producciones a las necesidades y exigencias del mercado de los Estados Unidos, de extraordinaria capacidad y muy adecuado para una amplia gama de nuestros productos". ${ }^{74}$ Durante esos nueve días en Nueva York, los riojanos mantuvieron la mayor parte de las reuniones, como ya se ha dicho, en el Centro Permanente de la Oficina Comercial que poseía el Ministerio de Comercio en la Avenida Madison. La embajada vitivinícola Riojana, como bien tituló La Gaceta una de sus noticias, recorrió las áreas metropolitanas, mantuvieron

71. Al fin, las bodegas representadas en esta primera exposición fueron: La Rioja Alta, López Heredia, Gómez Cruzado, Carlos Serres, Andrés de la Torre, Lacuesta, Franco Españolas, Ramón Bilbao, Rioja Santiago, CVNE, Bilbaínas, Riojanas, Montecillo, Riscal, Vizconde de Ayala, Savin, Paternina, Berberana y Romeral. Muchos habían puesto pegas, pero como siempre, cuando veían negocio, entraban en cualquier acto de promoción. FL Vivanco, caja 26. Folleto en inglés que recoge la presencia de otros vinos y marcas: Codorniú, Torres, Aquila Rossa, Destilerías Bravo y La Vinícola Ibérica (de Tarragona).

72. FL Vivanco, caja 26. La Gaceta del Norte, 21 de agosto de 1966.

73. AEVEH, La Gaceta del Norte, 21 de agosto de 1966 en la memoria de 1966, caja 1099.

74. La Gaceta del Norte, 27 de junio de 1966, FL Vivanco, caja 26. 
conversaciones con directivos de supermercados y de firmas detallistas, visitaron establecimientos, acudieron a la exhibición National Fancy Fodd and Confection Show y aseguraron el envío de grandes cantidades de folletos de propaganda, "incluyendo varios centenares de ejemplares en inglés del número que la revista Harpers dedicó recientemente a vinos de Rioja". ${ }^{75}$ La "embajada" fue un éxito, y Larrea, como hombre fuerte de la expedición, así lo exhibirá públicamente, con la satisfacción de haber colocado Rioja en el mapa de la distribución, y más importante aún, de haber colocado la marca con la seña de calidad hasta entonces desconocida en ese mercado, pues solo los franceses gozaban de esa categoría. Larrea lo dirá claro: "nuestro problema no es de calidad, sino de darnos a conocer". ${ }^{76}$ E irá más lejos aún, pues será tajante a la hora de descartar cualquier operación de promoción individual, y defenderá y apoyará los trabajos de la Asociación de exportadores de vinos y su campaña conjunta, que consistía básicamente en la creación de una etiqueta de botella única para cada tipo de vino, con la marca de la bodega incluida. Incluso se pensará en hacer un tipo único de vino para lanzar una marca colectiva. ${ }^{77}$ El éxito del viaje se prolongará hasta octubre de ese año, cuando miembros de la "Wine and Spirits Gulld of America" visitarán varias bodegas de Haro, Logroño y Fuenmayor, ${ }^{78}$ y el propio Larrea atenderá después, el 14 de ese mes, al comité de importadores de vinos y espirituosos de Francia. ${ }^{79}$

Otro de los efectos de la Feria de Nueva York fue, en efecto, la llegada a La Rioja de la citada delegación norteamericana de 20 hombres de negocios, encabezada por Richard Berenson, presidente de "Berenson and Liquor Marte", "la cadena de licores y vinos más importante de Estados Unidos, situada en Boston". Los americanos habían visitado Jerez, Valdepeñas y Madrid y pasaron unos días en La Rioja. Según Berenson, que había estado hacía 10 años en España, el cambio en la economía y en la industria españolas había sido espectacular. El americano veía también "ciudades más limpias y un pueblo activo y hospitalario", según decía el redactor de Nueva Rioja. ${ }^{80}$ Sin embargo, a pesar de que encontraba "buena calidad de los caldos y una industria a la altura de las mejores del mundo", era parco al pronunciarse sobre el sitio que podían ocupar los Rioja en su país. Berenson conocía perfectamente el mercado americano, cuya com-

75. La Gaceta del Norte, 27 de junio de 1966. FL Vivanco, caja 26.

76. El asunto de la publicidad y la promoción de ventas de vinos de Rioja a Estados Unidos ya había sido tratado por los Criadores-Exportadores y Embotelladores en reunión del 14 de septiembre de 1963. En el acta puede verse que preveían invertir entre 30.000 y 40.000 dólares anuales "para conseguir un impacto favorable en aquel mercado", si bien "se habla de que ya se están aumentando las exportaciones en medida importante, sin haberse todavía recurrido a propaganda". Acta en AHPLR, Fondo AISS, caja 585.

77. La Gaceta del Norte, sin fecha. FL Vivanco, caja 26.

78. "Han quedado gratísimamente impresionados por la calidad de los vinos y el volumen de las bodegas". El Correo Español, 9 de octubre de 1966. FL Vivanco, caja 26.

79. La Gaceta del Norte, sin fecha. FL Vivanco, caja 26.

80. AEVEH, Nueva Rioja, 9 de octubre de 1966 en la memoria de 1966, caja 1099. 
posición en materia de vinos era la siguiente: importaban 20 millones de dólares en vinos franceses, 4 en vinos italianos, 2,5 en vinos alemanes, 1,5 portugueses y solo un millón de dólares en vinos españoles. La mitad de ese millón era Rioja. El magnate del vino norteamericano decía que "los americanos nos fijamos mucho en la presentación, que no es muy buena. Buen vino y floja publicidad". En efecto, es lo que Larrea llevaba años repitiendo y ahora lo recalcará en cualquier intervención y en cualquier foro ${ }^{81}$.

Además de los americanos, visitaron La Rioja otros grupos de comerciantes extranjeros estimulados por lo que se divulgaba que ocurría desde la Exposición de Nueva York. La Asociación Francesa de Importadores de Vinos envió una expedición presidida por Mr. Baer que llamaba la atención al decir que venía a La Rioja con intención de "incrementar al máximo las exportaciones vinícolas de nuestra zona en su país". Declaraba a los periodistas: "los franceses apreciamos como nadie el vino de ustedes". ${ }^{82}$ Debió parecer algo sospechoso a los riojanos, cuando por otra parte se había ido difundiendo la oposición que encontraría España para entrar en el Mercado Común precisamente por competir en el mercado del vino con los franceses.

En 1966, las campañas prosiguen, las ventas aumentan. Don Antonio Larrea, en sesión del Consejo ante los exportadores, da cuenta, satisfecho, del éxito de la última campaña en "esta exposición", en referencia a la de Nueva York, y también expone sus reflexiones sobre lo que hay que hacer en el futuro. Según el presidente, que "se extiende en detalles relacionados con la organización del Certamen, vicisitudes que acaecieron debido a las irregularidades observadas en el transporte de los muestrarios, etc." -no nos sorprende su detallismo, obviamente-, "para años sucesivos los vinos de Rioja deberán acudir con planes perfectamente meditados que signifiquen un deseo de promocionar sus ventas, para lo cual considera ideal unificar esfuerzos y centrar la propaganda en una marca que ampare vino de calidad y que a su vez no sea un competidor en precios de las marcas particulares que en estos momentos vienen alcanzando ya en el mercado norteamericano notable desarrollo". ${ }^{83}$

El éxito de estas primeras campañas motivó cambios rápidamente, entre ellos, la confianza en estas misiones comerciales, que ya serían constantes y a distintos países como Alemania, Francia, o de nuevo, Estados unidos, al año siguiente. Tras la de 1966, varias bodegas se apuntaron para la siguiente, que ahora ya, se realizaría por varias ciudades norteamericanas. El Subgrupo había creado incluso

81. Ídem. Véase también Informe del viaje "Misión de vinos de Rioja" a Estados Unidos de Antonio Larrea, noviembre de 1967. FL Vivanco, caja 26.

82. AEVEH, Nueva Rioja, 14 de octubre de 1966 en la memoria de 1966, caja 1099; Tió Saralegui, C. (1986), La integración de la agricultura española en la Comunidad Europea. Mundi Prensa Libros.

83. FL Vivanco, caja 26. Carta de Enrique del Río al presidente del Subgrupo de Criadores-Exportadores, de 29 de septiembre de 1966, dando cuenta de la reunión del Consejo Regulador de 17 de septiembre. 
una comisión pomposamente llamada "de Promoción de Ventas en Norteaméri-

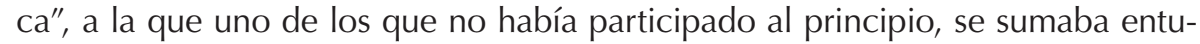
siasta, nada menos que CVNE, que el 18 de abril de 1967 escribía a la comisión ofreciendo para todo a su representante en Nueva York, que además les acompañaría también en Boston, en Chicago y en San Luis. El Consejo, sin embargo, no respondió a CVNE, que se lamentaba en 16 de agosto de no haber recibido contestación. ${ }^{84}$ Eran los chascarrillos habituales entre los grandes del vino, pero lo importante era que las cosas iban no solo bien, inmejorables, y el viaje de 1967, que al fin se hizo en octubre, fue todavía más exitoso que el anterior.

Dos años antes del periplo de octubre de 1967 a Nueva York, Rioja exportaba 1.167.912 litros a Estados Unidos, por un valor de 31.427.473 pesetas, mientras dos años después, en 1969, la cifra se triplicaba, pues alcanzaba el volumen de exportación un total de 3.274.443 litros, por valor de 128.418 .609 pesetas; ${ }^{85}$ cuatro años más tarde, la exportación a Estados Unidos se consolidaba, y suponía la venta de un total de 4.188.373 de litros, por valor de 211.909 .373 pesetas, cantidades solo superadas por Suiza. Con todo, el producto que se asentaba en USA era la sangría, de la que en ese año de 1973 se habían exportado 221.360.242 litros por valor de 589.059 .788 pesetas. $^{86}$

El vino dejaba de ser un producto complementario, importante para la economía regional, y pasaba a convertirse en un producto global, imprescindible para la economía riojana, a la que iba a servir de motor. Los años 66-67 conocerán el mayor salto cualitativo en la historia del vino de Rioja en materia de internacionalización. El viaje de 1966 a USA había sido en palabras de Larrea "de orientación y sondeo para ver posibilidades", ${ }^{87}$ pero será al año siguiente cuando la misión de abrir nuevos mercados en los Estados Unidos se acompañe de una campaña promocional de antemano que tendrá ya definidos sus objetivos prioritarios: conseguir que el vino suba de precio $^{88}$ para elevar su prestigio, y en consecuencia ganarse al mercado norteamericano ofreciendo calidad. Y ahí entraba la promoción, puesto que "digan lo que digan, la calidad precisa de promociones publicitarias más que el tenedor para comer". ${ }^{89}$ Para ello, se invertirían 11.000 dólares en la campaña de publicidad, distribuyéndose además 4.000 folletos en inglés sobre vinos de Rioja, y se enviarían nada menos que más de

84. FL Vivanco, caja 26.

85. Datos de exportación del Consejo Regulador de la Denominación de Origen Rioja de los años 1965 y 1969. AHPLR, Fondo AISS, caja 585.

86. Información estadística correspondiente a las exportaciones de vino y sangrías realizadas durante el año de 1973. AHPLR, Fondo AISS, caja 585.

87. La Gaceta del Norte, 1 de octubre de 1967. FL Vivanco, caja 26.

88. Los periódicos destacarán que el vino francés se vendía ocho dólares por encima del riojano, según Nueva Rioja, e incluso hasta veinte dólares por encima según destacará el propio Larrea en La Gaceta del Norte. FL Vivanco, caja 26.

89. Ídem. 
7.500 botellas para las distintas degustaciones. ${ }^{90}$ Pero el círculo se cerraba en el precio y la calidad, la calidad y el precio. Y también la unidad de los exportadores para poder atender pedidos muy voluminosos. Larrea afirmará que "Estados Unidos es el primer consumidor de vino embotellado que potencialmente ya es un vino de calidad. Nuestro propósito $-y$ es un propósito que va entrando en todos los bodegueros- es poder ofrecer al mercado un tipo de vino uniforme de buena calidad, que podría competir con los franceses e italianos y daría garantías para un consumo masivo". Y es que a mayor calidad mayor precio, extremo que se estaba consiguiendo, según afirmaba Ángel Gutiérrez, vicepresidente del Consejo y Delegado Regional de Comercio, quien exponía que las exportaciones en ese año podrían dar un valor total de 53 millones de pesetas, debido a que "hemos duplicado los ingresos por ventas sin que la proporción en venta de litros haya seguido una línea paralela". ${ }^{91}$ Pero no todo eran parabienes, pues El Correo Español, el Pueblo Vasco apuntaba también los problemas, entre los que cabe destacar la ausencia de un vino uniforme para formar frente común, la desunión entre los pequeños cosecheros y la baja producción de crianza. ${ }^{92}$

La Misión comercial de exportadores de vinos de Rioja, subvencionada por la Dirección General de Expansión Comercial, se decidiría tras las conversaciones mantenidas entre la Comisaría de Expansión Comercial, el Consejo Regulador y el Grupo de Exportadores, y estuvo de nuevo encabezada por Antonio Larrea, otra vez como presidente del Consejo Regulador de Origen Rioja y otra vez acompañado de su esposa, Julia Caño, y esta vez viajaría reforzando su papel y complementándolo Ángel Gutiérrez Escudero, vicepresidente del Consejo y Delegado Regional de Comercio. La delegación la completarían José Luis Santaolalla, de AGE, Juan de Ugarte, de Bilbaínas, Rolf Hieronimi, de Franco Españolas, Theodor Hochberg, de Montecillo, Marcelo Frías, de Bodegas Riojanas, Santiago Calleja, de Rioja Santiago, Francisco Ibernia, de Paternina, Dionisio Arnedo, de La Rioja Alta, José María Martínez, de Martínez Lacuesta y Anastasio Gutiérrez, de López de Heredia. Además, también estaba representada CVNE, aunque no nominalmente como las anteriores, como ya se ha visto. ${ }^{93}$ El viaje arrancó el 16 de octubre de 1967 y se prolongó hasta el 4 de noviembre. Durante esas más de dos semanas, visitaron cinco ciudades de Estados Unidos: Nueva York, Boston, Chicago, San Luis y Washington, ${ }^{94}$ y contaron con el apoyo de personalidades destacadas que recibieron a los miembros de la Misión, tales como el

90. Según Nueva Rioja, se enviarían 633 cajas, 58 por cada bodega. Nueva Rioja, 1/10/1967. FL Vivanco, caja 26.

91. Ídem.

92. El Correo Español, el Pueblo Vasco, 1 de octubre de 1967. FL Vivanco, caja 26.

93. Relación de las personas que integraban la Misión en la carta de Andrés Acedo, Secretario del consejo Regulador, a Fernando Uriarte, director de Viajes Internacional Expreso, SA, sin fechar. FL Vivanco, caja 26. 88.

94. Copia del programa elaborado por la Agencia Conant \& Company. FL Vivanco, caja 
cardenal Spellman ${ }^{95}$ y los alcaldes de Chicago y San Luis, lo que Larrea siempre valorará mucho, pues "las visitas a personalidades resultan convenientes por la publicidad que suponen para los vinos de Rioja". ${ }^{96}$ Larrea se pronunciará así en el Informe que sobre el viaje redactó, y gracias al cual podemos establecer la metodología que seguirían y también las conclusiones y recomendaciones que él mismo, como cabeza de la delegación, dejaba anotadas para el proceder futuro. La estructura de trabajo consistía, básicamente, en lo siguiente: un "lunch" o entrevista con representantes de la prensa, las visitas a las personalidades ya citadas y una degustación por las tardes, actividad central para la Misión, pues en ella se desplegaba el potencial del Rioja como un vino de calidad. Las degustaciones se celebraron en los salones que los hoteles habilitaban para tal efecto, excepto en Nueva York, que se celebró en el Centro Permanente de España, y en las mismas cada exportador tenía una mesa donde colocaba sus botellas, propaganda y vasos, todo ello en semicírculo o en un círculo completo en el salón, por cuyo centro iban pasando los visitantes, que podían probar de todos los vinos acompañados de queso, avellanas y patatas fritas. Había también un tiempo libre cada día que cada exportador aprovechaba individualmente, y que normalmente dedicaban a realizar entrevistas y ultimar contactos.

Entre los numerosos actos, el vicepresidente del Consejo organizó una reunión con los exportadores, a la que invitó al Mr. Conant, el dueño de la agencia que iba a estudiar mercados y sondear la posibilidad de una marca común -lo que rechazaban muchos bodegueros-, y analizar las futuras líneas de actuación, pero "solamente se cambiaron impresiones, no habiendo acuerdos". ${ }^{97}$ Larrea, en su informe de dos páginas, especialmente en la segunda, "juzgará" adecuadas las ciudades elegidas para realizar la Misión, valorará la conveniencia de concertar citas con personalidades, como ya se ha dicho, y desarrollará dos "juicios contrapuestos" sobre las degustaciones: Larrea dirá que no era necesario invitar a mucha gente, "y menos sacando sus nombres de un anuario siendo suficientes unos importadores fuertes", pero sí en cambio se hacía necesario "hacer una llamada lo más general posible" para crear "un ambiente de conocimiento y demanda", pues el "vino de Rioja es casi desconocido". Larrea culminará su informe con cuatro "líneas de acción": una, "no menudear esta clase de viajes", dos, "seleccionar los exportadores por el negocio de exportación que tengan ya con Estados Unidos, o por una potencia de producción que les permita servir la demanda que tengan caso de buenos resultados", tres, la conveniencia de que los técnicos viajen con las misiones comerciales "por la repercusión posterior en su gestión", y cuatro, "tener muy presente que esta índole de viajes son representativos y genéricos, no teniendo por qué financiar la administración viajes que se

95. "Afectuosidad en la audiencia del cardenal Spellman a los exportadores, titularía La Gaceta del Norte. La Gaceta del Norte, 27 de octubre de 1967. FL Vivanco, caja 26.

96. Informe del viaje "Misión de vinos de Rioja" a Estados Unidos de Antonio Larrea, noviembre de 1967. FL Vivanco, caja 26.

97. Ídem. 
limiten solo a tratos con importadores". ${ }^{98}$ Larrea dejaba así su sello inconfundible en estas "líneas de acción", aconsejando la dosificación de las misiones, la selección de los integrantes y sus objetivos, el papel imprescindible de los técnicos y la asunción por parte de los exportadores de los costes de la promoción, una vez impulsada ésta por los poderes públicos. El precursor de la exportación de Rioja a Estados Unidos como un producto de primera calidad marcaba así los futuros pasos que debían darse para consolidar esta vía de negocio, convertida en prioritaria por necesaria. Y aconsejaba, por último, la permanencia de una de las grandes cualidades de los hombres del Rioja desde siempre: la intuición.

\section{Conclusiones}

Partimos de la constatación de la escasez de fundamentos de la actual moda de llamar a todo cultura del vino, lo que ya provocaba hasta el enfado de Larrea, que distinguía muy bien entre las buenas prácticas de divulgación y propaganda de aquellas otras que no tenían más sentido que el de vender más vino. Hay varios artículos de Larrea en ese sentido. Él se sumó entusiasmado en los años 50 a los primeros certámenes de exaltación del Rioja, y todavía en su vejez disfrutó de algunas Ferias, tanto en La Rioja como en otras capitales del vino; sin embargo, criticó la publicidad avasalladora de ciertas Ferias en los 80 , cuando ya el consumismo lo invadía todo. Él había recomendado beber hasta una botella de tres cuartos al día, como vimos en el artículo publicado en Berceo, pero ante la publicidad grotesca en algunos casos llegó a exclamar iquieren que beban vinos hasta las niñas! Así pues, la conclusión es que Larrea tenia clara la línea que había que seguir en cuanto a la cultura del vino, que no era la simple propaganda, sino por el contrario, la comprensión de una actividad humana que distingue a los pueblos en todos los sentidos: económicamente, pues es evidente la diferencia de las tierras con y sin vino; clave en el comercio, como demuestra el monopolio del Rioja en el País Vasco y en Cantabria, tierras sin vino, de las que el viaje de retorno traía todo tipo de productos, incluidos los coloniales que llegaban a sus puertos; pero también clave en cuanto que la viña y el vino producen un complemento de renta agraria, lo que Larrea interpretó en varios artículos como causa de que en las zonas vitivinícolas riojanas pudiera frenarse la emigración. A la vez, socialmente, pues Larrea, de origen castellano, aunque naciera en Baeza, acabo siendo un hijo de Haro y conociendo perfectamente a la gente del mundo del vino de esa ciudad única que lleva dos siglos siendo no solo la capital del Rioja, sino el símbolo de esa manera de ser que produce la cultura del vino, generalmente visible en comportamientos abiertos, francos y progresistas.

La Guerra Civil había producido un enorme daño en la agricultura riojana, falta de materiales, de herramientas e incluso de ganado de labor, pues una buena parte de la cabaña mular y caballar estaba movilizada en el ejército de Franco.

98. Ídem. 
Cuando se está haciendo frente a la pura supervivencia en el campo, en medio de la II Guerra Mundial y del aislamiento, Larrea tiene que tomar las riendas de un centro envejecido con un personal rutinario y escaso de medios. Esa situación la arrastrará toda la vida, por eso le veremos lamentar año tras año las estrecheces de la institución. Cuando además tenga que presidir el Consejo Regulador, los lamentos aumentarán de tono, pues como él dirá ese es un "organismo inoperante". En definitiva, Larrea no tuvo para desarrollar su labor ni medios ni apoyos. Y aun con todo, y de una manera callada por tenaz y resolutiva fue capaz de atravesar los difíciles años 50 y llegar a los sesenta poniendo al Rioja en el mundo. Todavía a finales de los setenta, Larrea escribía proyectos para bodegas, firmaba informes para explotaciones vitivinícolas, seguía dando conferencias y enseñando a los viticultores, y por supuesto, mantenía las suscripciones a revistas especializadas de todo el mundo y seguía leyendo sobre cualquier innovación técnica. En el umbral de la jubilación, descubrimos a un nostálgico Larrea que es capaz de manifestar su enorme reverencia por la investigación y la ciencia, pero también su sensatez al confesar que ha de dejar paso a otros. En suma, los cuarenta años de Larrea fueron para el Rioja una constante evolución en calidad, en beneficios y en crear una cohesión social en la región, clave también entre otras para lograr la autonomía.

\section{Bibliografía}

ALONSO CASTROVIEJO, J. J. (1992), Problemática agraria, solución burguesa, Logroño, 1750-1833, Logroño, Instituto de Estudios Riojanos.

ALONSO CASTROVIEJO, J. J. (2001), "Estado historiográfico de la investigación sobre el viñedo en La Rioja. Siglos XIX y XX". I Encuentro de historiadores de la Vitivinicultura Española. El Puerto de Santa María, pp. 425-434.

BARCO ROYO, E., (2013), Factores determinantes del funcionamiento económico del sector vitivinícola en la Denominación de Origen Calificada Rioja (DOCa Rioja) y su adaptación a los cambios en el entorno económico. Tesis doctoral, Universidad de La Rioja, noviembre 2012.

BERMEJO MARTíN, F. y DELGADO, J. M. (1989), La Diputación Provincial de La Rioja. Logroño.

BERMEJO MARTÍN, F. y DELGADO, J. M. (1993), "La economía riojana desde una perspectiva histórica", Papeles de Economía Española.

BORRELL MERLÍN, M. D. (2006), "Historia y cultura del Rioja. El marqués de Murrieta", Berceo, 150, pp. 169-188.

COELLO MARTíN, C. (2008), Las Bases Históricas y Administrativas del Derecho Vitivinícola Español. El Sistema jurídico de las Denominaciones de Origen, Instituto Andaluz de Administración Pública, Sevilla.

DE LA FUENTE ROSALES, F. (2011), "Capítulo 7. La Estación Enológica", Temas Jarreros II, Haro, Ayuntamiento de Haro, pp. 321-393. 
DE LAS HERAS Y NÚÑEZ, M. Á. (1995), "La vitivinicultura altomedieval riojana y la miniatura mozárabe Autores", Berceo, 129, pp. 97-112.

EGIDO, A. (2005), La Estación Enológica de Haro. Un referente para la ciencia y la técnica del vino desde 1892, Logroño, Ediciones La prensa del Rioja.

GALLEGO MARTÍNEZ, D. (1987), "El factor agrario riojano, 1855-1935. De la especialización vitícola a la diversificación de la producción agraria", Brocar. Cuadernos de Investigación Histórica, 12, pp. 45-88.

GOMÁ LANZÓN, J. (2013), "Raptado por las musas", Babelia, El País, 17 de agosto de 2013.

GÓMEZ URDÁÑEZ, J. L. (dir.) (2000), El Rioja histórico. La Denominación de Origen y su Consejo Regulador, Logroño, Consejo Regulador, pp. 88-92.

GÓMEZ URDÁÑ̃Z, J. L. (dir.) (2008), Empresarios trabajadores. Historia de la Federación de Empresarios de La Rioja. Logroño.

HUETZ DE LEMPS, A. (1967), Vignobles et vins du nord-ouest de l'Espagne. Burdeos, Presses Universitaires de Bordeaux.

LARREA REDONDO, A. (1964), "Hacia la promoción de la viticultura española", en La Semana Vitivinícola bajo el título "Temas vitivinícolas de actualidad", números 936-37, 938, 940, 942, 946, julio-septiembre de 1964, Valencia.

LARREA REDONDO, A. (1951), "Viticultura y enologías riojanas", Berceo, 20, pp. 343-356.

LASANTA MARTíNEZ, T. (1999), "Evolución reciente del mercado del Rioja y cambios en el sector vitivinícola", Berceo, 136, pp. 193-214.

LUEZAS PASCUAL, R. A. (2000), "Testimonios arqueológicos en torno a la vid y el vino en La Rioja", Berceo, 138, pp. 7-38.

MEES, L. (1992), "La vitivinicultura en Navarra y La Rioja: Economía, sociedad y política de intereses (1850-1940)", Gerónimo de Ustáriz.

NAVAJAS ZUBELDIA, C. (1995), "'Cosecheros' contra 'Comerciantes'. Los antecedentes inmediatos de la creación del Consejo Regulador de la Denominación Vinícola 'Rioja'", Berceo, 129, pp. 175-188.

ORTIZ RODRÍGuEZ, J. L. (2000), "El Sindicato Nacional de la Vid", en Maldonado Rosso, Javier y Ramos Santana, Alberto, Actas del I Encuentro de Historiadores de la Vitivinicultura Española, Puerto de Santa María.

PAN MONTOJO, J. (1992), La vitivinicultura en España, 1750-1988, Madrid, MAPA.

PAN MONTOJO, J. (1993), El Estado y la vid. Los orígenes de la política agraria en España a través de la vitivinicultura, 1847-1923, Madrid, Servicio de Publicaciones de la Universidad Autónoma de Madrid.

PAN MONTOJO, J. (1994), La bodega del mundo. La vid y el vino en España, Madrid. 
PASCUAL CORRAL, J. y LEÓN SÁENZ, J. (coords.) (1992), 1892-1992. Estación Enológica de Haro, cien años de historia, Logroño, Gobierno de La Rioja, Consejería de Agricultura y Desarrollo Rural.

SÁENZ CENZANO, S. (1951), "Estado actual y posibilidades de la agricultura en La Rioja", Berceo, 20, pp. 357-374.

SÁINZ RIPA, E. (1995), "Viñas y vinos en la comarca calceatense durante los siglos XIII, XIV y XV", Berceo, 129, pp. 113-137. 